\title{
IMPLEMENTASI PENDIDIKAN KARAKTER DI SMP NEGERI 1 TELUK GELAM DALAM MENGATASI SIKAP PRIMODIALISME
}

\author{
${ }^{1}$ Evi Agustina dan ${ }^{2}$ Tobari \\ ${ }^{1}$ Kepala Madrasah Ibtidaiyah Daarul Aitam \\ ${ }^{2}$ Universitas PGRI Palembang \\ e-mail: daarulaitam09@gmail.com
}

\begin{abstract}
Indonesia is currently in a multidimensional crisis, the moral shift of teenagers is very significant, if it is not immediately anticipated, it will have an impact on the destruction of a State. In order to overcome it, it is very necessary that the values of the characters are implemented on learners early, so that they have a life prinsiple in building and continuing the journey of this country. One of the most credible concepts of education as a solution of primodialism is character education. SMP Negeri 1 Teluk Gelam has conducted character education to minimize the perimodialism attitude. Because the generation that is prepared now is a generation that will continue the establishment of the Unitary Republic of Indonesia. The research used qualitative research method of ethnography by describing character education conducted at SMP Negeri 1 Teluk Gelam namely (1) Aperception which is associated with religious values by every subject teacher 5 minutes before learning begins; (2) Applying discipline; (3) Implementation; (4) Habituation activities; (5) cooperation with Tanjung Lubuk Polsekta in guiding the students; (6) Active communication with parents.
\end{abstract}

Keywords: Character Building, SMP Negeri 1 Teluk Gelam, Primodialism

PENDAHULUAN

Indonesia adalah salah satu negara multikultural terbesar didunia, kebenaran dari pernyataan ini dapat dilihat dari sosio kultur maupun geografis yang begitu beragam dan luas. Dengan wilayah NKRI yang memiliki 14,572 pulau yang terdiri dari pulau besar dan kecil, dengan jumlah penduduk 254,9 juta jiwa,terdiri dari 300 kelompok etnis, 1.340 suku bangsa yang menggunakan 1.211 bahasa yang berbeda (BPS: 2010). Selain itu juga menganut agama dan kepercayaan yang beragam seperti Islam, Katholik, Kristen protestan, hindu, budha, konghucu, serta berbagai macam kepercayaan (Diknas: 2004).
Keragaman ini diakui atau tidak, akan dapat menimbulkan berbagai macam persoalan seperti yang sekarang ini terjadi pada bangsa kita. Seperti korupsi, kolusi, nepotisme, premanisme, perseteruan politik, kemiskinan, kekerasan, separatisme, tawuran antar pelajar, perkelahian antar teman karena rasa egoisme, sikap sukuisme, yang berujung pada tawuran antar dusun yang sekarang banyak terjadi dipedesaan (merdeka.com, 2014). Rasa primodialisme yang tinggi juga salah satu faktor terjadinya perkelahian di sekolah, argumen primordialis menunjukkan bahwa perbedaan yang tak terdamaikan karena kesenjangan budaya menyebabkan ketakutan dan konflik yang melahirkan 
kekerasan (Nicholas, 2001). Menurut Kamus

Besar Bahasa Indonesia

$(\mathrm{KBBI})$

primodilaisme adalah perasaan kesukuan yang berlebihan, perusakan lingkungan dan hilangnya rasa kemanusiaan untuk selalu menghargai hak-hak orang lain adalah bentuk nyata dari mengikisnya jiwa nasionalisme. Priomodial yang diartikan sebagai ikatan-ikatan dala sebuah masyarakat yang bersifat keaslian seperti kesukuan, kekerabatan, keagamaan dan kelompok atau sifat yang dibawa sejak lahir, yang sifat keasliannya ini misalnya berdasarkan kesukuan, kekerabatan "klan” dan kelompokkelompok tertentu yang bersifat tradisional (Setiawan, 2016).

SMP Negeri 1 Teluk Gelam adalah lembaga pendidikan yang berorientasi pada pengembangan kualitas peserta didik dan mengutamakan pengembangan akhlak (spiritual) melalui pembelajaran dengan pendekatan keagamaan, adapun pengembangan kualitas peserta didik dilakukan melalui kegiatan kurikuler, kokurikuler dan ekstrakurikuler sedangkan pengembangan akhlak dilakukan dengan pendekatan keagamaan melalui kegiatan pembiasaan, bimbingan dan ketauladanan (Dok.1 Kurikulum SMPN 1 Teluk Gelam).

Visi SMPN 1 Teluk Gelam adalah "Unggul dalam prestasi berdasarkan iman dan taqwa berwawasan lingkungan" serta

Misinya adalah (1) melaksanakan pembelajaran dan bimbingan secara efektif sesuai dengan potensi masing-masing siswa, (2) menumbuhkan semangat keunggulan bagi segenap warga sekolah, (3) Membantu dan menolong setiap siswa mengenali potensi dirinya sehingga dapat berkembang secara optimal (4) Menumbuhkan pengahayatn terhadap agama yang dianut serta budaya bangsa sehingga menjadi sumber kearifan dalam bertindak, (5) Menerapkan manajemen partisiatif dengan melibatkan keseluruhan warga sekolah dan pihak sekolah. (Dok.1 Kurikulum SMPN 1 Teluk gelam).

Banyak prestasi baik akademik maupun non akademik yang diperoleh oleh sekolah ini. Karena keinginan yang keras antara guru dan siswa, terbukti dengan prestasi yang berhasil dicapai siswa seperti Juara 2 lomba story telling tk. Provinsi, Juara 1 Gerak Jalan putra Tk. Kecamatan, terpilih sebagai salah satu peserta untuk mengikuti perkemahan di Cibubur dari Sumsel yang diperoleh sekolah ini. Selain itu, siswa kami merupakan siswa yang gigih dan semangat sekali untuk belajar, ada sebagian dari mereka berasal dari dusun-dusun yang jauh dari sekolah dan menempuh sekolah dengan berjalan kaki. Dalam kegiatan ekstrakurikuler pu mereka sangat antusia, 
Ujar Irsan, S.Pd ( Waka kesiswaan SMPN 1 Teluk Gealam).

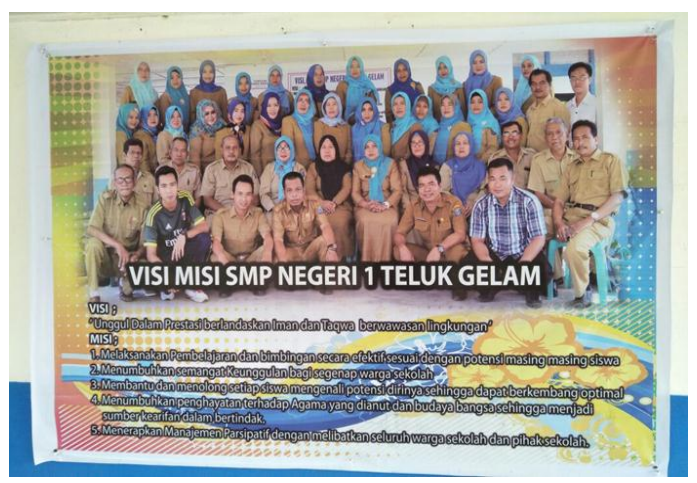

SMPN 1 Teluk Gelam adalah SMPN

Yang berlokasi di Sumatera Selatan Kabupaten Ogan Komering Ilir dengan alamat Jl. Raya Komering Ds. Muara Telang. Berdasarkan wilayah tempat tinggal, sekolah ini berada dilingkungan masyarakat suku komering. Suku komering adalah salah satu suku yang terdapat di Sumatera Selatan, mereka adalah suku penjelajah sehingga menyebarannya sampi ke daerah Lampung, menurut hikayat masyarakat komering, mereka berasal dari dari dua saudara yang datang dari negeri seberang, setelah sampai di sumatera mereka terpisah, kakak pergi ke selatan, sebagai puyang suku komering dan adik pergi ke utara sebagai puyang suku batak. Oleh karena itu orang Komering merupakan masyarakat yang dikenal bertempramen cukup tinggi dan keras (Puspita :2017). Dilihat dari karakter masyarakatnya, suku komering dikenal memiliki temperamen yang tegas (Lubis :2015).
Berdasarkan latar belakang di atas pulalah yang membentuk watak kepribadian setiap siswa SMPN 1 Teluk Gelam, sehingga rasa egoisme sangat mendominan pada diri mereka, yang kadang kala memicu pertengkaran di antara peserta didik itu sendiri, misalnya jika salah satu teman mereka melihat dengan terlalu lama saja dianggap menjeliti (bahasa daerah setempat: melihat dengan sombong) maka lawan yang dilihat tadi langsung menantang untuk berkelahi, siswa yang ditantangpun akan menyampaikan ini pada temannya satu dusun dan secara beramai-ramai mendatangi siswa menantang tadi yang juga sudah siap menunggu terjadilah perkelahian diantara mereka yang biasanya dapat diselesaikan dengan melibatkan orang tua, kades dan kepolisian untuk menghindari terjadi saling serbu antar dusun atau menjaga keamanan bagi siswa yang mungkin cidera dalam perkalian tersebut, karena jika tidak segera diselesaikan ujungnya pasti saling serbu antar dusun atau sekolah ini akan didatangi oleh warga sedusun, untuk membalas dendam pada siswa yang telah melukai anak dusunnya. Kejadian ini terjadi sangat sering sekali bahkan sampai 6 kasus dalam setahun dan dilakukan secara turun temurun maksudnya dilakukan juga oleh adik kelasnya. (Wawancara dengan Wakasek 
kesiswaan Bapak Irzan, SPd pada tanggal 13 Nopember 2017 )
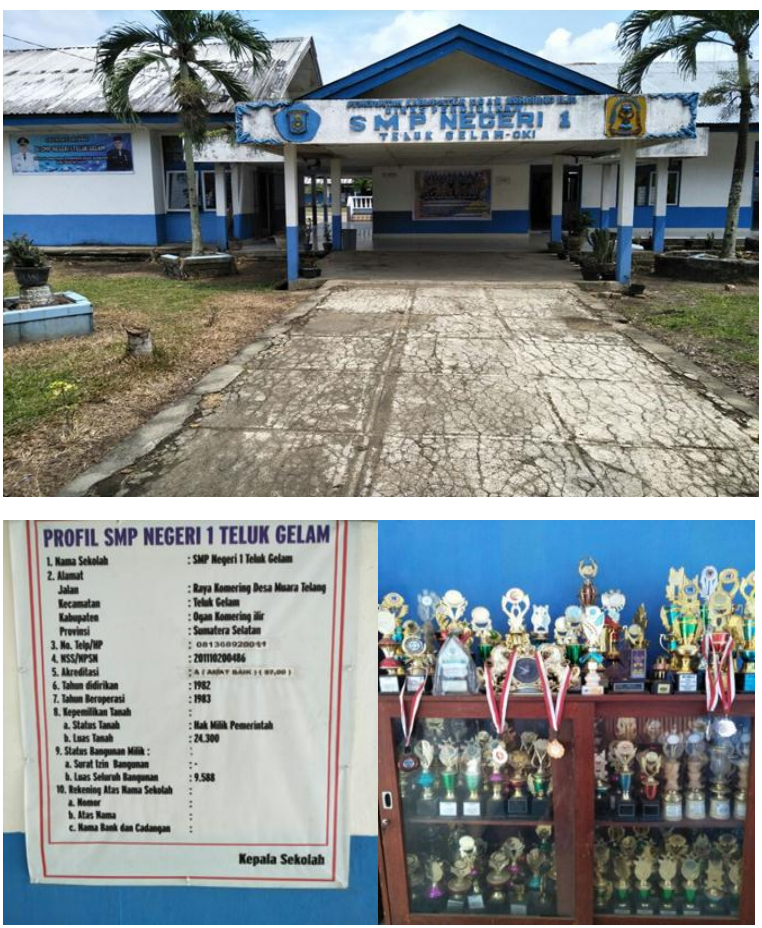

Berdasarkan cerita diatas, dapat disimpulkan salah satu watak kepribadian siswa SMPN 1 Teluk Gelam, adalah rasa egoisme dan temperamental yang tinggi sehingga memunculkan sikap primodialisme dalam diri siswa sejak kecil. Menurut William G. Summer (1907) bahwa primodialisme adalah di dalam in groups terdapat persamaan persaudaraan yang ditunjukkan dengan kerajasama, yang saling membantu dan saling menghormati serta memiliki persamaan solidaritas, kesetiaan terhadap kelompoknya dan kesediaan berkorban demi kelompok. Dalam meminimalisir hal ini SMPN 1 Teluk Gelam mengimplemetasikan pendidikan karakter dalam proses pembelajaran.

\section{METODE PENELITIAN}

Dalam penelitian ini, penulis menggunakan metode Kualitatif Etnograpi. Menurut Sugiyono (2011) Metode Penelitian kualitatif adalah metode penelitian yang berlandaskan pada filsafat postpotivisme, digunakan untuk meneliti pada kondisi obyek yang alamiah, dimana peneliti adalah sebagai instrument kunci, pengambilan sampel sebagai sumber data dilakukan secara purposive dan snowball, tehnik pengumpulan data dengan Triangulasi (gabungan), analisis data bersifat induktif/kualitatif dan penelitian kualitatif lebih menekankan pada makna dari pada generalisasi. Sedangkan Penelitian Kualitatif Etnografi yaitu suatu bentuk penelitian yang berfokus pada makna sosiologi melalui obsevasi lapangan tertutup dari suatu fenomena sosiokultural (Emzir : 2013). "Etnography literally means 'a portrait of e people.' An ethnography is a written description of particular culture the customs, beliefs, and behavior based on information collected through fieldwork (Marvin Harris and Orna Johnson, 2000). Menurut Gunawan (2015) Penelitian kualitatif etnografi adalah metode penelitan berdasarkan pengamatan terhadap sekelompok orang dengan lingkungan yang alamiah.

Penelitian ini mengacu pada penelitian sosial yang memiliki karakteristik 
(Emzir: 2013) sebagai berikut: 1) merupakan penelitian terhadap prilaku siswa SMPN 1 Teluk gelam dalam konteks sehari-hari. Berupa sikap egoisme dan temperamen yang berujung pada sikap primodialisme yakni sikap sukuisme yang berlebihan, dan rasa solidaritas yang tinggi antar siswa satu dusun sehingga jika terjadi penganiayaan siswa yang sedusun dengannya maka sangat merasa berdosa jika tidak ikut solidaritas dengan menyerang balik siswa yang tadi diserang, hal ni meruapak langkah awal dari penelitian ini dengan mendefenisikan suatu permasalahan yakni antara sikap primodialisme dangan pengimplemetasian pendidikan karakter pada siswa. 2) Data dalam penelitian ini dikumpulkan melalui observasi lapangan adalah metode pengumpulan data dengan mengamati secara langsung di lapangan. Mengamati bukan hanya melihat, melainkan juga merekam, menghitung, mengukur, dan mencatat kejadian-kejadian yang ada (Nazir: 2011).

Menurut Prasitowo (2011) obsevasi adalah pengamatan langsung para pembuat keputusan berikut lingkungan fisiknya dan atau pengamatan langsung suatu kegiatan yang sedang berjalan. Sesuai dengan defenisi diatas penulis melakukan observasi langsung ke SMPN 1 Teluk gelam pada tanggal 13 November 2017 mengamati pola tingkah laku siswa, guru dan mengikuti pembinaan yang disampaikan oleh perwakilan Kapolsek Tanjung Lubuk dalam amanah upacara bendera hari senin Adapun keuntungan dari observasi lapangan adalah data yang diperoleh memiliki tingkat keabsahan yang tinggi, dapat melihat langsung apa yang dikatakan dan dilakukan/aktifitas yang dilakukan oleh partisifan, dapat menggambarkan lingkungan fisik dari kegiatan-kegiatan yang dilakukan partisifan, dan dapat mengukur kegiatan yang dilakuka dalam waktu tertentu.(Prasitowo :2011).

Kemudian dilakukan wawancara, wawancara menurut Nazir (2011) adalah proses memperoleh keterangan untuk tujuan penelitian dengan cara Tanya jawab sambil bertatap muka antara si penanya atau pewawancara dengan si penjawab atau responden dengan menggunakan alat yang dinamakan interview guide (panduan wawancara). Wawancara merupakan salah satu metode pengumpulan data penelitian dimana dalam pelaksanaannya terjadi proses percakapan untuk mengkonstruksi mengenai orang, kejadian, kegiatan, organisasi, motivasi, perasaan dan sebagainya yang dilakukan dengan dua pihak yakni pewawancara dengan orang yang diwawancarai, Bungin (2007).dapat disimpulkan bahwa wawancara adalah cara memoeroleh data melalui Tanya jawab anatar pewawancara dan audien untuk memperoleh 
keterangan tentang suatu kejadian atau masalah penelitian (Margono, 1997). masalah, pada zaman modern ini wawancara Sedangkan Menurut Arikunto (2006) tidak hanya dapat dilakukan dengan Tanya "Dokumentasi adalah mencari dan jawab face to face tapi juga bisa memalui mengumpulkan data mengenai hal-hal yang media misalnya video call (vc), melalui WA, berupa catatan, transkrip, buku, surat kabar, email dan sebagainya karena melalui alat majalah, notulen, rapot, agenda dan sebagainya".

Jadi dapat disimpulkan bahwa yang bersamaaan jika kejadian dan informasi berlangsung secara bersamaan.dalam penelitian ini, penulis melakukan wawancara dengan Kepala Sekolah, Wakil kepala bagian kurikulum, wakil kepala bagian kesiswaan, Pembina osis dan ketua osis sebagai perwakilan siswa SMPN 1 Teluk Gelam.Adapun wawancara pada sebuah penelitian berfungsi sebagai metode primer, pelengkap atau kriterium (Hadi, 1992) sebagai data primer, wawancara merupakan data utama bagi peneliti untuk menjawab permasalahannya. Sebagai metode pelengkap hasil wawancara berfungsi sebagai pelengkap metode lainnya untuk mengumpulkan data suatu penelitian. Sebagai kriterium, hasil wawancara digunakan untuk menguji kebenaran hasil penelitian yang diperoleh dari metode lain sebelumnya.

Metode dokumentasi atau dokumenter adalah cara mengumpulkan data melalui peninggalan tertulis seperti arsiparsip dan buku-buku tenang pendapat, teori atau hokum yang berhubungan dengan

Metode dokumentasi diartikan sebagai suatu pengumpulan data yang diperoleh dari dokumen yang ada baik berupa surat kabar, album foto, buku, jurnal, transkrip dan sebagainya. Dalam penelitian ini, Penulis mengumpulkan data berdasarkan dokumentasi sekolah berupa Dokumen I dan II Kurikulum SMPN 1 Teuk Gelam, Profil Sekolah, foto-foto kegiatan sekolah. 3) pendekatan untuk pengumpulan data tidak terstruktur. Menurut Emzir (2013) pendekatan untuk pengumpulan data tidak terstruktur artinya melibatkan penggunaan suatu set rencana terperinci yang disusun sebelumnya, juga tidak menggunakan kategori yang telah ditetapkan sebelumnya untuk penginterpretasian apa yang dikatakan dan dilakukan orang. Sedangkan Nazir (2011) mengartikan bahwa dalam pendekatan ini si peneliti tidak mengetahui aspek-aspek apa dari kegiatan yang ingin diamatinya relevan dengan tujuan penelitiannya. Peneliti juga tidak mempunyai suatu rencana tentang cara-cara pencatatan 
dari pengmatannya, sebelum ia memulai mengumpulkan data. 4) fokus penelitian merupakan suatu latar tunggal atau skala terkecil artinya dalam penelitian etnografi focus penelitian dapat berupah individu tunggal atau sekelompok kecil. Sehingga penelitia hanya meneliti siswa dilingkungan SMPN 1 Teluk Gelam; 5) analisis data melibatkan interpretasi arti dan fungsi tindakan manusia dan sebagian besar mengambil format deskripsi verbal dan penjelasan yakni tindakan seluruh stakholder SMPN 1 Teluk Gelam yang tertuang pada program sekolah sebagai antisipasi dari sikap perimodialisme tersebut

\section{HASIL PENELITIAN DAN PEMBAHASAN}

SMP N 1 Teluk gelam dalam pelaksanaan pendidikan baik kurikuler, ko kurikler maupun ekstra kurikuler telah memasukkan pendidikan karakter. Sesuai dengan UU No.2 tahun 2003 tentang sisdiknas pendidikan adalah usaha sadar dan terencana untuk mewujudkan suasana belajar dan proses pembelajaran agar peserta didik secara aktif mengembangkan potensi dirinya untuk memiliki kekuatan spiritual keagamaan, pengendalian diri, kepribadian, kecerdasan, akhlak mulia, serta keterampilan yang diperlukan dirinya, masyarakat, bangsa dan Negara. Menurut suyanto (2009) pendidikan karakter adalah cara berpikir dan berperilaku yang menjadi ciri khas tiap individu untuk hidup dan bekerja sama, baik dalam lingkup keluarga, masyarakat, bangsa, maupun negara. Model pembelajaran karakter yang diterapkan di SMPN 1 Teluk Gelam.

Dalam proses pembelajaran, setiap guru diwajibkan 5 menit sebelum pembelajan dimulai harus memberikan Apersefsi yang berkaitan dengan nilai-nilai agama.(Hasil wawancara dengan M.Tanjung, S.Pd, waka kurikulum) Pada dasarnya setiap manusia telah memiliki potensi berbuat baik dimana perkembangannya akan dipengaruhi oleh pemikirannya sendiri atau dipengaruhi oleh ideology tertentu, atau aliran ideology yang ia yakini, serta juga nilai-nilai ajaran agama yang dianut. Ideology berisi rumusan produk pemikiran manusia. Sedangkan agama berisi ajaran bersumber dari wahyu ilahi (Jalaluddin, 2011: 113)karena prinsif inilah guru senatiasa mengingatkan siswa untuk menggali potensi kebaikan dalam diri siswa melalui pendekatan nilai-nilai agama. pengembangan nilai moral dilakukan melalui proses internalisasi. Nilai-nilai moral yang diaktualisasikan pada peserta didik. Di sisi yang lain peserta didik diberikan pemahaman betapa pentingnya kecerdasan emosional dan kecerdasan spritual lewat internalisasi atau menghayati nilai moral tersebut. Dikarenakan konsep keimanan dapat naik 
turun atau menipis, oleh karena itu sebuah keharusan dilakukan internalisasi baik secara rasional maupun lewat penghayatan (Muhajir, 2003: 164).

Menerapkan disiplin, setiap siswa diwajibkan saling bersalaman dengan guru dan sesama siswa ketika masuk kekelas, jika ada yang salah salah sama lainnya harus saling meminta maaf dengan berjabtan tangan, dan mematuhi semua peraturan yang telah ditetapkan di sekolah (Hasil wawancara). Menurut johar permana, Nursisto (1986: 14) disiplin adalah sustu kondisi yang tercipta dan terbentuk melalui proses dan serangkaian prilaku yang menunjukkan nilai-nilai ketaatan, kepatuhan, kesetiaan, keteraturan dan ketertiban. Disiplin sekolah "refers to students complying with a code of behavior often known as the school rules" Wikipedia, (1993: 115). Disiplin mengajarkan rasa tanggung jawab siswa baik pada dirinya, sekolah dan masyarakat.

Keteladanan, guru dalam menjalankan tugasnya mempunyai kewajiban seperti yang tercantum dalam UU No.14 tahun 2005 tentang guru dan dosen pada pasal 14 ayat 1 yaitu (1) Merencanakan pembelajaran, melaksanakan proses pembelajaran yang bermutu, serta menilai dan mengevaluasi hasil pembelajaran; (2) Meningkatkan dan mengembangkan kualifikasi akademik dan kompetensi secara berkelanjutan sejalan dengan perkembangan ilmu pengetahuan, teknologi, dan seni; (3) Bertindak objektif dan tidak diskriminatif atas dasar pertimbangan jenis kelamin, agama, suku, ras, dan kondisi fisik tertentu, atau latar belakang keluarga, dan status sosial ekonomi peserta didik dalam pembelajaran; (4) Menjunjung tinggi peraturan perundangundangan, hukum, dan kode etik guru, serta nilai-nilai agama dan etika, dan; (5)Memelihara dan memupuk persatuan dan kesatuan bangsa.Dari kewajiban diatas jelas sekali jika guru harus menjadi contoh yang baik bagi peserta didik terutama dalam hal memupuk rasa persatuan dan kesatuan,sehingga guru tidak bersifat primodialisme ditengah keberagaman suku di lingkungan SMP N 1 Teluk Gelam. Selain itu hal ini ditanamkan pula kepada siswa kelas tinggi yang diaharapkan dapat memberikan contoh kepada adik kelasnya bagaimana yang tua memperlakukan yang muda dan yang muda menghargai yang tua. contoh b sehingga tumbuhlah rasa kebersamaan dan saling melindungi. Pendidikan karakter memerlukan metode khusus yang tepat agar tujuan pendidikan. Diantara metode pembelajaran yang sesuai adalah metode ketauladanan, metode pembiasaan, dan metode pujian dan hukuman (www.lyceum.id). guru sebagai 
penuntun dan yang ditonton siswanya, mampu menjadi figur yang wajib dicontoh siswa dan orang sekelilingnya. Berbuat sesuai perkataan, bertingkah laku sopan, santun, dan bijaksana, mampu menyenangkan orang- orang sekelilingnya. Terlebih siswanya, penuh kasih sayang pada sesama, arif dan bijaksana dalam memutuskan suatu perkara. Semoga semua guru menjadi idola bagi siswanya (www.cnnindonesia.com).

Kegiatan Pembiasaan, dilakukan pembiasaan membaca yasin bersama setiap hari jumat pagi dengan harapan jiwa siswa akan merasakan ketentraman dan mengurangi sifat temperamen dan egoisme. "Orang-orang yang beriman dan hati mereka menjadi tenteram dengan mengingat Allah, ingatlah, hanya dengan mengingat Allah hati menjadi tenteram" (QS. Ar Ra'du 13:28); dalam ajaran Islam sangat diyakini adalah salah satu sumber ketenangan hati dan pengendlian emosi adalah dengan membaca Al-Quran,hal ini dijelaskan didalam AlQur' an surat Al-Anfal ayat 2 "Sesungguhnya orang-orang yang beriman itu adalah mereka yang apabila disebut nama Allah gemetarlah hati mereka, dan apabila dibacakan kepada mereka ayat-ayat-Nya bertambahlah iman mereka (karenanya) dan kepada Tuhanlah mereka bertawakal".Terdapat 11 ayat didalam Al-Qur'an yang merupakan fondasi dalam pendidikan Islam, yang membuat manusia memiliki jiwa yang tenang dan dapat mengembangkan dirinya sesuai dengan fitrahnya terutama bagi generasi muda yang perlu bimbingan dan pembinaan dalam mengendalikan diri dan mengenal jati dirinya karena siswa tingkat menengah biasanya masih dalam masa penasaran dan ingin mencoba segala sesuatu yang baru dilihatnya karena itu model pendidikan karater pada usia anak-anak harus diberikan untuk pembentukan karakter (Kristiawan, 2016). Sehingga mereka dapat menjadi generasi bangsa yang unggul dan beriman.

Berkoordinasi dengan pihak polsek Tanjung Lubuk untuk memberikan nasehat tentang nilai-nilai kebersamaan, rasa saling menyayangi dan bahaya perkelahian antar siswa yang mengakibatkan perpecahan kepada peserta didik dalam amanah upacara bendera hari senin sebanyak 2 bulan 1 kali. serta Melakukan komunikasi aktif kepada wali siswa, perlu ada kerja sama dan komunikasi yang baik antara sekolah dan keluarga dalam mengembangkan karakter anak remaja (Kristiawan, 2016). Melalui pertemuan rutin 3 bulan 1 kali membahas permasalahan peserta didik dan bersamasama mencari jalan keluarnya. (Hasil wawancara dengan Kepala Sekolah SMPN 1 Teluk Gelam, Evi Sepriati, S.Pd : 13 Nop 2017) 

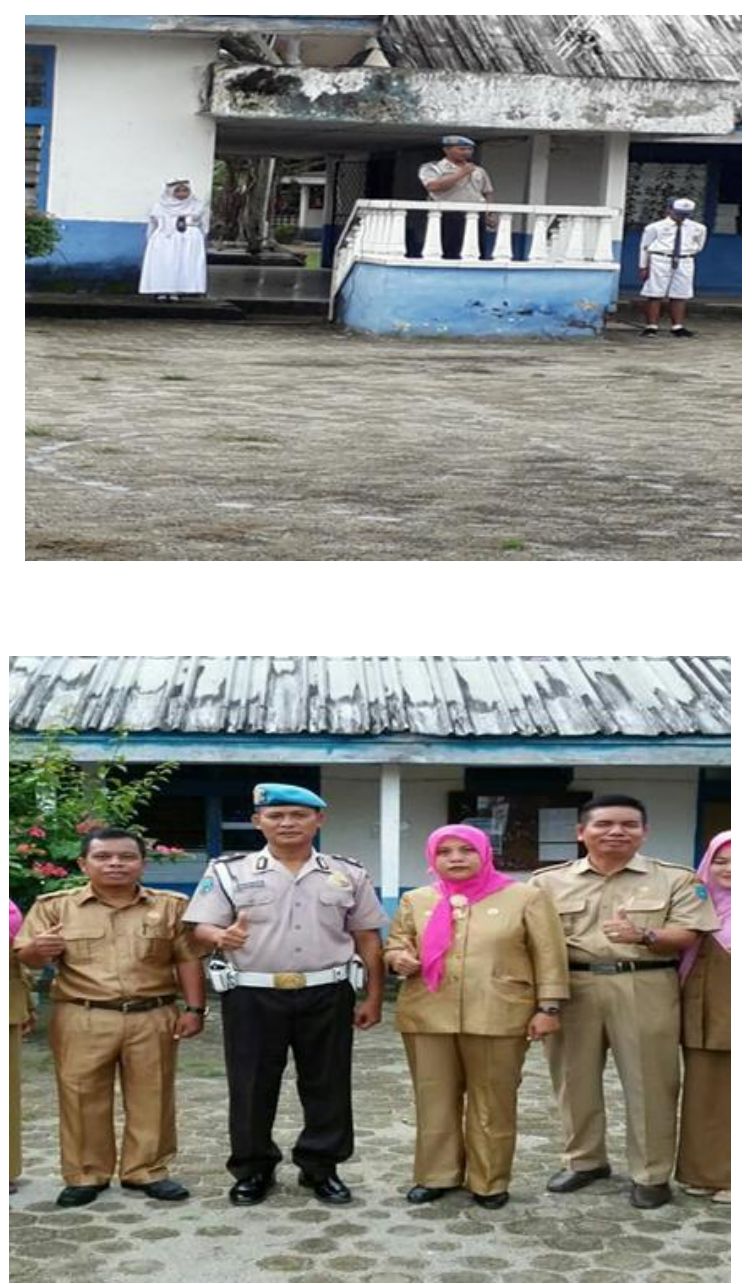

Selain kegiatan diatas, OSIS juga punya program tersendiri yakni ceramah siraman rohani yang seluruh rangkaian kegiatannya dilakukan oleh pengurus OSIS sementara penceramahnya mulai dari kepala sekolah hingga guru-guru diberi jadwal untuk mengisi ceramah, hal ini dilakukan setiap hari jum'at diikuti oleh seluruh siswa SMPN 1 Teluk Gelam, kegiatan ini tertulis lengkap dalam program kegiatan OSIS ( Hasil wawancara dengan Pembina OSIS SMPN 1 Teluk Gelam, Fransiska, S.Pd :13 Nop 2017). suatu usaha yang disengaja untuk membantu seseorang sehingga ia dapat memahami, memperhatikan, dan melakukan nilai-nilai etika yang inti (lickona :2009)Seluruh kegiatan tersebut dilaksanakan secara optimal sejak 2 tahun terakhir ini, hasilnya sudah menunjukkan kemajuan, dalam satu tahun ini saja tidak terjadi perkelahian kalaupun ada, hanya sebatas masalah kecil, anak tidak melibatkan tementeman sedusun lagi dan cepat dapat diatasi oleh guru piket saja (Hasil wawancara dengan Waka kesiswaan:13 Nop 2017).

Penelitian Endang (2015) pendidikan karakter di SMK N 2 Porworejo melalui (1)pelaksanaan karakter siswa dilakukan oleh pelajaran PPKn, Agama, dhuzur bersama, pramuka ekstrakurilkuler; (2)kepala sekolah melatih guru dan staf taat dan bertanggungjawab; (3)peraturan sekolah dan kerjasama dengan orang tua; (4)Budaya sekolah dilakukan dengan pembiasaan. Sedangkan temuan Agus Sudarsono (2016) bahwa pendidikan karakter di SMP N 2 dan MTs Wahid Hasyim Yogyakarta dilakuakn dengan (1) kepala sekolah, guru dan ustadz memiliki pengertian yang memadai tentang pendidikan karakter; (2)Implementasi pendidikan kkarakter melalui nilai-nilai relegius dengen mengintegrasikan inkulkasi nilai dalam seleuruh aktivitas siswa baik dalam pembelajaran, ekstra kurikuler, kegiatan belajar, mengaji, makan, istirahat 
dan lainnya: (3)pendidikan karakter telah dirancang oleh waka kuriklum: (4)peran serta seluruh steakholder sekolah dalam mengimlementasikan pendidikan karakter.

Dari kajian tentang pengimplemetasia pendidikan karakter tersebut tidak terlepas dari peran serta orang tua, guru dan masyarakat dan ketauladan serta pembiasaan merupakan metode pengeimplementasian pendidikan karakter tersebut. Senada dengan hasil temuan Ahmad dkk (2014) yang menyebutkan bahwa Strategi yang dilakukan SMA Plus Negeri 2 Banyuasin III dalam pembelajaran karakter dan menjaga mutu lulusan adalah membentuk budaya sekolah, yaitu perilaku, tradisi, kebiasaan keseharian, dan simbol-simbol yang dipraktikkan oleh semua warga sekolah, dan masyarakat sekitar sekolah. Semua guru SMA Plus Negeri 2 Banyuasin III harus menjadikan dirinya sebagai sosok teladan yang berwibawa bagi para siswanya.

Komunikasi antara guru dan orang tua sangat diperlukan karena yang dapat membentuk karanter peeserta didik adalah lingkungan baik lingkungan keluarga maupun lingkungan sekolah. Lingkungan sekolah (guru dan siswa) memiliki peran yang kuat dalam membentuk karakter anak (Kristiawan, 2016). Artinya pendidikan karakter tidak akan pernah sukses jika tanapa kerjasama orang tua sebagai lingkungan terkecil bagi peserta didik.karena selain ketauladanan dan pembiasaan itu dilakukan disekolah oleh guru, sedangkan dirumah peserta didik harus menemukannya melalui orang tua sehinngga singkronisasi antara pendidikan disekolah dan dirumah terlaksana dengan baik. Maka akan menghasilkan peserta didik yang baik sesuai dengan tujuan pendidikan nasional kita, dan diharapkan dapat mengatasi berbagai krisis moral dinegeri kita ini terutama sikap primodialisme dalam diri siswa.

\section{KESIMPULAN}

Dalam mengatasi sikap primodialisme dalam diri siswa yang disebabkan oleh sikap egoisme dan temperamen tinggi di SMP N 1 Teluk Gelam adalah pengimpelemtasian pendidikan karakter melalui kegiatan kurikuler, ko korikuler dan ekstra kurikuler berupa (1) Apersefsi yang dikaitkan dengan nilai-nilai keagamaan oleh setiap guru mata pelajaran 5 menit sebelum pembelajaran dimulai; (2) Menerapkan disiplin; (3) Ketauladanan; (4) Kegiatan pembiasaan; (5) Bekerjasama dengan polsekta Tanjung Lubuk dalam pembinaan siswa; (6) Komunikasi aktif dengan orang tua siswa. Upaya ini dilakukan secara intensive sehingga sesuai dengan tujuan pendidikan. 


\section{DAFTAR PUSTAKA}

Ahmad, S., Kristiawan, M., Tobari, T., \& Suhono, S. (2017). Desain Pembelajaran SMA Plus Negeri 2 Banyuasin III Berbasis Karakter Di Era Masyarakat Ekonomi ASEAN. Iqra (Educational Journal), 2(2), 403-432.

Arikunto, S. (2006). Metodologi Penelitian, Yogyakarta, Bina Aksara.

Bungin. (2007). Pengertian Wawancara. dalam http://elvantediofawaz.blogspot.co.id/ 2016/pengertianwawancara.html

Badan Pusat Statisik 2010.

Departemen Agama. (2012). Al-Qur'an dan Terjemah. Semarang: PT.Karya Toha.

Departemen Pendidikan dan Kebudayaan 2004.

Dokumen I Kurikulum SMP N 1 Teluk Gelam

Emzir, (2013), Metoodologi Penelitian Pendidikan, Jakarta, PT. Grafindo Persada.

Gunawan, Imam, dalam fip.um.ac.id/wpcontent/uploads/2015/12/7._Etnografi .pdf

Haris, Marvin dan Johnson Oma, (2000) dalam Metodologi Penelitian Pendidikan, Emzir, 2013.

Hadi, (1992), dalam http://merlitafutriana). Blog-spot.co.id/p/wawancara.html

Jalaluddin, (2011), Filsafat Pendidikan Islam, Jakarta, Kalam Mulia.
Kristiawan, M. (2016). Telaah Revolusi Mental Dan Pendidikan Karakter Dalam Pembentukkan Sumber Daya Manusia Indonesia Yang Pandai dan Berakhlak Mulia. Ta'dib, 18(1), 1325.

Lubis, Bangun, (2015), dalam http//www.kompasian.com

Merdeka. Com, (2014)

Margono. (2007). Metologi Penelitian Pendidikan Komponen MKDK.Jakarta, PT. Rineka Cipta.

Muhadjir, Noeng. (2003). Ilmu Pendidikan dan Perubahan Sosial. Yogyakarta: Rake Sarasin

Nazir, Moh., (2011), Metode Penelitian, Bogor Penerbit Ghalia Indonesia.

Puspita, Mely, (2017), kenali suku-suku di Sumatera Selatan, https//lifestyle.okezone.com/2017/ke nali suku-suku di sumatera selatan.

Prasetio, Andi. (2011), Pengertian tehnik wawancara dan observasi dalam http://dunia-penelitian.blogspot.co.id/ 2011/10/pengertian-teknikwawancara-observasi.html

Permana, Johar dan Nursisto, (1986), Pengertian Disiplin dan Penerapannya dalam javafardyanz.blogspot.com/2012/ 03/pengertian-disiplin-danpenerapannya.html.

Sudarsono, Agus, Sudrajat, Satryo Wibisono, (2016), Implementasi Pendidikan Karakterb di SMP Negeri 2 dan MTs Wahid Hasyim Yogyakarta, Jurnal UNY

Susilowati, Endang, (2015), Implementasi Pendidikan Karakter di SMK Negeri 2 Purworejo, Penelitian Program Studi 
Pendidikan IPS, Univ.PGRI

Yogyakarta

Sugiono, (2011), Metode Penelitian

Kuantitatif, kualitatif dan R7D,

Bandung, CV. Alfabeta.

Suyanto, (2009), Implementasi Pendidikan Karakter melalui Pembelajaran

Terpadu dalam staff.uny.ac.id

Sambanis, Nicholas, (2001), Do Ethnic non Ethnic Civil Wars Have The same Causes? A. Theoretical and Empirical Inquiry, Journal of Conflict Resulation, 45 .

Summer, William G.,(1907), dalam rosyyonalisa.blogspot.co.id/2017/04/pe ngertian-primodialisme.html

Tilaar, HAR, (2002), Pendidikan Kebudayaan dan Masyarakat Madani Indonesia, Jakarta, Remaja Rosdakarya.

Tilaar, HAR, (2002), Perubahan Sosial Pensisikan: Penguatan PaedagogikTranspormatif Untuk Indonesia, Grasindo, Jakarta. 
JMKSP

Jurnal Manajemen, Kepemimpinan, dan Supervisi 